\title{
ON FURTHER THOUGHT: \\ LUCAS OF TUY, RODRIGO OF TOLEDO AND THE ALFONSINE HISTORIES'
}

\author{
PETER LINEHAN \\ St. John's College, University of Cambridge \\ (Great Britain)
}

For Barrie Dobson, con todo afecto

Alfonso X of Castile's death in April 1284 presented Western Europe with a paradox: the paradox of a kingdom on the verge of political disintegration yet possessed of the most ambitious historiographical project of its time. Or almost possessed of it -because of course by 1284 Alfonso $\mathrm{X}$ 's project for Spain's national past had already been frustrated by Castile's present politics.

Even so, what had been achieved in less than two generations was . remarkable. In historiographical terms, the kingdoms of Castile and León until the 1230s had been an under-developed area. At least as regards the recent past, Lucas of Tuy had started with almost nothing recognizable to us as historical material, depending largely on a combination of epic sources and men's (or, as has often been supposed, old women's) memories, supplemented by his own fertile imagination. Additionally, it has been

\footnotetext{
'A revised version of a talk given at the Seminario "Alfonso el Sabio y las 'Crónicas de España'" under the auspices of the Fundación Duques de Soria (Soria, July 1997). I am grateful to all those present on that happy occasion, both the young and the not so young, for their comments, and in particular to Mariano de la Campa, Inés Fernández-Ordóñez, and Georges Martin.

"Anuario de Estudios Medievales", 27 (1997)
} 
surmised, he had access to "sources now lost or at least unknown"2, which on more counts than one sound uncannily like that unknown source, 'al parecer fidedigna', adduced by Menéndez Pidal as the authority for everything in the Alfonsine history which could not otherwise be accounted for $^{3}$. And likewise Rodrigo of Toledo, dubiously assisted in his case by the bishop of Tuy's recent lucubrations.

An English historian of the same period may be forgiven for wondering at the causes of the poverty of the historiographical tradition to which Lucas of Tuy and Rodrigo of Toledo were heirs. On the one hand there is the explanation offered by Vicente de Lafuente a century ago, that churchmen were generally otherwise engaged servicing the warriors of the Reconquest ${ }^{4}$; on the other, Santillana's maxim, that "la sçiençia non enbota el fierro de la lança, ni faze floxa la espada en la mano del cavallero" ${ }^{5}$. In part, the existence of the "Crónica Najerense" suggests that Santillana may have been right $^{6}$. But only in part, for the narration of the "Crónica Najerense" ends with the death of Alfonso VI in 1109. To reformulate the question, then, why was it that contemporary history was so strangely neglected in Alfonso VIII's Castile? ${ }^{7}$. Any consideration of the historiographical quickening in his grandson's reign must take account of this inherited torpor.

It is certainly remarkable how much busier than their Spanish brethren English monks were in the century after 1150. Our knowledge of the history of England in these years is founded on the contrasting and overlapping accounts of a whole galaxy of monastic writers. (Only in the

\footnotetext{
${ }^{2}$ B.F. REILLY, Sources of the Fourth Book of Lucas of Túy's 'Chronicon Mundi', "Classical Folia", XXX (1976), p. 135.

${ }^{3}$ As to which see J. M. LaCARra, El lento predominio de Castilla, "Revista Portuguesa de Historia", XVI (1976), p. 76; Peter LINEHAN, History and the Historians of Medieval Spain, Oxford, 1993, p. 463.

4"La Iglesia de España ha seguido la suerte del Estado en su próspera y adversa fortuna, alentando al combate, exhortando en la pelea, consolando en la derrota, y cortando las rencillas y discordias fraternales: en los escasos momentos de ócio ha manejado la pluma, mientras el guerrero descansaba apoyado en su lanza": Historia eclesiástica de España, 2nd edn, III, Madrid, 1873, pp. 379-380.

SÍñigo López de Mendoza, Marqués de Santillana, Obras completas, ed. A. Gómez MORENO and M.P.A.M. KERKHOF, Barcelona, 1988, pp. 218-219.

${ }^{\circ}$ Chronica Naierensis, ed. J. A. EstÁvez SOLÁ, Corpvs Christianorvm Continvatio Mediaevalis [hereinafter CCCM] 71A, Turnout, 1995.

${ }^{7}$ Cf. Linehan, History, pp. 246-248.
} 
seventeenth century did the records of government begin to be added to such of those monastic accounts as protestants in the sixteenth had failed to obliterate $)^{8}$. It is instructive to compare the quality of the historical material that was available to Lucas of Tuy and Rodrigo of Toledo with what their English contemporary, Matthew Paris, was able to deploy.

Although he was no more than a monk of his monastery, the account that Matthew Paris provided of his life and times is richer in every respect than that of D. Rodrigo, chancellor of Castile and archbishop of Toledo. Nulla est comparatio ${ }^{9}$. We may wonder why it was that the English monk (who died in 1259) has so much more to tell us about the history of his time than the Castilian archbishop chooses to reveal, why it was that whereas the mere monk of St Albans reproduces the texts of numerous royal and papal documents in extenso, the archbishop of Toledo, ex officio chancellor of Castile, never does so. Despite the devotion he had for the church of Toledo on account of which he accumulated innumerable copies of papal privileges in its favour, not a few of which he cites in his chronicle, only once does D. Rodrigo so much as refer to a public instrument ${ }^{10}$. Other than on this occasion, for his account of the recent Castilian past he relies on his own recollections of the years since he came to Toledo in 1209. For the years before, the historian-archbishop follows in the footsteps of Lucas of Tuy, if only to erase them, and to that extent may not unfairly be described as part-journalist, part-plagiarist.

As to contemporary events, we may start with the two chroniclers' respective accounts of the reunion of the kingdoms of Castile and León in 1230 , an event which mattered much to both our writers. In referring to it as a "reunion" I am begging a question of course. By treating the concomi-

${ }^{8}$ D. C. Douglas, English Scholars, 1660-1730, 2nd edn, London, 1951. In the case of Castile, government censorship came earlier, with the appropriation of Alfonso's historiographical initiative and the systematic denigration of Alfonso himself immediately after his death:J.R. CradDock, Dynasty in dispute. Alfonso X el Sabio and the succession to the throne of Castile in history and legend, "Viator", XVII (1986), pp. 197-219. Cf. A. IGLESIA FERREIRÓs, Alfonso $X$, su labor legislativa y los historiadores, "Historia. Instituciones. Documentos", IX (1982), pp. 32-53.

${ }^{9}$ R. Vaughan, Matthew Paris, Cambridge, 1958, esp. pp. 17-18 for the English chronicler's use of Exchequer material; A. GRANSDEN, Historical Writing in England, c. 550-c.1307, I, London, 1974, pp. 356-379.

${ }^{10} \mathrm{Namely}$, the certificate that Berenguela was the elder of Alfonso VIII's daughters: De rebus Hispanie [hereinafter $D R H$ ], IX. 5, ed. J. FERNÁNDEZ VALVERDE, Historia de rebvs Hispanie sive Historia Gothica, CCCM 72, Turnout, 1987, 286 $11-12$ 
tance of the two kingdoms as normative, I am in danger of appearing to imply that there was something unnatural about the separation of them decreed by Alfonso VII in 1157. In fact that separation had not been unnatural at all. It had been entirely in accordance with custom - exactly as the separation of England and Normandy in 1087 had been, just twenty-one years after the Norman conquest of England". We must beware of importing to the eleventh and twelfth centuries assumptions of territorial aggrandizement that belong to the nineteenth, or, for that matter, of imposing upon them the categories of the thirteenth (those of Alfonso $\mathrm{X}$ for example) $)^{12}$.

There was nothing unnatural about the partition of Alfonso VII's inheritance at the time. Yet to the author of the "Crónica latina de los reyes de Castilla" some eighty years on that was how it seemed. Writing soon after the reunion (or union) of the kingdoms of León and Castile, the bishop of Osma sought a moral explanation for the phenomenon and found one in the sins of men: "permittente Deo propter peccata hominum"13. Alfonso X would be preoccupied by divisio regni too, though by its effects rather than its causes, on account of "[el] danno que uino en ella por partir los regnos, por que se non pudo cobrar tan ayna"14. Not so the bishop of Tuy, however. Lucas reports the ante mortem act of his great hero Alfonso VII as a matter of fact, without comment ${ }^{15}$. It is Rodrigo of Toledo, at one with Juan of Osma in expressing the "official mind", who ascribes blame, and states that the division was done on the advice ("consilio"') of the counts of Lara and Trastámara, "discidia seminare uolencium"16.

\footnotetext{
"LaCarra, El lento predominio, pp. 63-81. Cf. J. C. Holt, Politics and property in early medieval England, "Past \& Present", 57 (Nov. 1972), pp. 3-52, esp. pp. 12-19.

${ }^{12} \mathrm{Cf}$. J. M. FERnÁndez CATÓN's description of the divisio regni of 1157 as [un] "grave error político": Colección documental del Archivo de la Catedral de León (775-1230), V (1109-1187), León, 1990, p. XII.

${ }^{13}$ Crónica latina de los reyes de Castilla, ed. L. Charlo BreA, Cádiz, 1984, p. 8.

${ }^{14}$ Estoria de España [hereinafter EE], prólogo: Primera Crónica General de España [hereinafter $P C G$ ], ed. R. MENÉNDEZ PIDAL, Madrid, 1955, p. $4 \mathrm{~b}_{13-14}$.

${ }^{15}$ Chronicon Mundi [hereinafter $C M$ ], ed. A. SchotTus, Hispania Illustrata, IV, Frankfurt, 1608, p. $105_{44}$

${ }^{16} D R H$, p. $229_{21.2}$, whence $P G C$ cap. 876: "por conseio de los condes...que metien desabenencia et contiendas de muerte entre los grandes omnes del regno, et esto era lo que ellos querien segunt cuenta ell arçobispo" (p. $655 \mathrm{a}_{29-36)}$.
} 
So at this crux of peninsular history, the year 1157 , it was Rodrigo not Lucas who pointed the finger at the territorial nobility - which is the very opposite of what their respective treatment of other events of the peninsular past, and Georges Martin's remarkable account of it (to which I shall shortly be returning), might have led us to expect. According to Lucas, history taught that Spain's past calamities had been self-inflicted, by her own nobility ("Si quis percurrat historias diligenter, fere nunquam inueniet Gotthos praeliis superatos, nisi contra ipsos manus quoque Gotthica repugnaret" $)^{17}$. In his account of 1157 , therefore, Lucas was not playing true to form.

Nor, in another respect, was he, it would seem, in his account of 1230 , that crucial year for Spanish history and Spanish historiography alike. Without the reunion of the kingdoms in that year the Alfonsine compilers some forty years later would have lacked a territorial focus for their work. What the events of 1230 represented at the time, however, was something else, namely the triumph of Castilian hegemony and the culmination of an ideological process whose beginnings fifty years before have been identified independently, and from different standpoints, by Martin and myself ${ }^{18}$. And for Lucas the Leonese patriot this ought to have counted as a disaster. For his "Chronicle of the World" was not about the world at all. It was about his world. The world of Lucas's title soon narrows to Spain, and Spain to León. His opening treatise "De Excellentia Hispaniae" is an unrestrained panegyric on León, both patria and civitas: "Quae patria vel quae ciuitas vt Legio urbs Hispaniae tale quid protulit, quam Christi martyrem Marcellum centurionem cum [...] Christi martyribus edidit quorum sanguine \& fide plebs catholica roboratur"19. (When the time came D. Rodrigo's partisanship would take a different form).

In reporting Fernando III's acquisition of the 'kingdom' of León simply in terms of the "royal city" of León (civitas regia), therefore, Lucas appears unaccountably aloof from his subject. It is as if he were recording an event in the history of ancient Rome. He does so with all the appearance

\footnotetext{
${ }^{17} C M$, p. $39_{48.50}$.

${ }^{18} \mathrm{G}$. Martin, Les Juges de Castille. Mentalités et discours historique dans l'Espagne médiérale, Paris, 1992, pp. 111-52; LINEHAN, History, pp. 287-312.

${ }^{19} \mathrm{CM}$, p. $2_{23.26}$.
} 
of total detachment ${ }^{20}$. There is nothing whatsoever in his account to reveal that as a canon of $\mathrm{S}$. Isidoro de León he was a witness of these stirring events $^{21}$, even less that he was emotionally involved in their outcome. It is only in Rodrigo's much better informed version of them that we encounter a sense of immediacy ${ }^{22}$. Rodrigo was part of his own story: "Sequenti uero die intrauimus Legionem"23. (He had been part of his own story since $1211)^{24}$. Lucas by contrast is the great anonymous and, of the two, the true professional.

Lucas is impassive; he gives nothing away. What can we say of one of whose biography so little is known before his promotion to the see of Tuy in 1239, yet whose work stands at the fountainhead of what Martin has justly described as "le plus grand mouvement historiographique du moyen âge espagnol"? ${ }^{25}$ His chronicle has been described as an "eirenic" work, as a "chronicle of reconciliation" to celebrate the reunion of the two kingdoms ${ }^{26}$. Nothing, I think, could be further from the truth; I shall return to the point. But first I turn to his stated intention, as formulated in his Preface.

Lucas presents his history as a moral treatise, as a vademecum of good government for the guidance of the king, a discourse on the Isidorian dictum "Rex dicitur a regendo". Right rule begins with self-rule, in accordance with a series of moral precepts addressed to King Fernando III and enunciated by the king's mother, Berengaria of Castile.

Now although we know that Lucas ended his work in $1236^{27}$, we do not know when he began it. But if, as I assume, he did so after 1230, then Berengaria's "catholic precepts", with their warnings against wine and women ${ }^{28}$, might appear inappropriate. After all, the "princeps delicatus" to whom they are addressed was not a delinquent adolescent but a warrior king

\footnotetext{
${ }^{20} C M$, pp. $114_{56}-115_{30}$.

${ }^{21}$ Cf. Crónica latina, p. 84.

${ }^{22} D R H$, IX.14-15 (pp. $295_{10}-297_{27}$ ). Cf. $P C G$. caps. $1038-9$ (pp. $722 \mathrm{~b}_{14}-724 \mathrm{~b}_{3}$ ).

${ }^{23} \mathrm{DRH}$, IX.15: p. $296_{3}$.

${ }^{24}$ Ibid, VII.36: p. $258_{24}$

${ }^{25}$ MARTIN, Les Juges, p. 204.

${ }^{26} \mathrm{M}$. Recuero Astray, La conciencia histórica, in L. SuÁREZ FERnÁndez, et al., León en torno a las Cortes de 1188, s.l., s.f., (¿León? 1988), p. 108.

${ }^{27}$ Or perhaps that it was interrupted in that year. It ends untidily there in the Schottus (i.e. Mariana) edition.

${ }^{28} C M$, pp. $1_{31-34}, 3_{56-57}$.
} 
in his thirties well on his way to fathering nine children. But that would be to underestimate his mother. Berengaria had played a decisive role in securing for Fernando both his kingdoms, in the case of the kingdom of Castile at the cost of the entire bequest she had had from her father ${ }^{29}$. By Lucas's own account that "most prudent" lady continued to exercise an iron discipline over her son, "as though he were still a little boy"30. The fact that Fernando III was the first king of his line not to be detected in adultery $^{31}$ was doubtless due to mother. So too, perhaps, is the fact that there is no mention of 'majesty' in Lucas of Tuy's preface, as there would be in D. Rodrigo's ${ }^{32}$.

Berengaria's continuing tutelage of her grown-up son matches that of Blanca, her sister. The redoubtable Blanche of Castile, the mother of Louis IX of France, was a severe matron too, with strict rules. Sooner death than adultery (her son's adultery, be it understood). Indeed she was scarcely willing even to let Louis sleep with his wife, Joinville reported, or to allow him to console her when she had suffered a miscarriage. The royal couple's ushers had instructions to warn them of Blanche's dread approach ${ }^{33}$. With justice, Jacques Le Goff describes the situation which continued until her death as "une coroyauté", as "[une] sorte de cogouvernement" ${ }^{34}$. Where Le Goff is mistaken is in regarding the French situation as "exceptionelle". It was not. It was paralleled in Castile. The parallel held good right until the deaths of the two queen-mothers - though when the time came, for whatever reason, Fernando controlled his grief better than his French cousin $\mathrm{did}^{35}$.

As to the inspiration of Lucas's chronicle, may there not also have been another parallel between these two viragos, between "ces deux femmes qui se ressemblaient tant par leur caractère et par le rôle qu'elles eurent à

\footnotetext{
${ }^{29}$ Charlo Brea, Crónica latina, p. 55.

30 "Etenim ita obediebat prudentissimae Berengariae Reginae matri suae, quamuis esset regni culmine sublimatus, ac si esset puer humillimus sub ferula magistrali": $C M$, p. $112_{37-38}$.

${ }^{31}$ Ibid., p. $112_{48-50}$.

${ }^{32} \mathrm{DRH}$, pp. $6_{54}, 7_{90}$

${ }^{33}$ Jean de JoInville, Histoire de Saint Louis, II.119, ed. M. NATAlis DE MaILly, Paris, 1874, p. 333; J. LE GoFF, Saint Louis, Paris, 1996, pp. $709 \mathrm{ff}$.

${ }^{34}$ Ibid., p. 714.

${ }^{35}$ On Berengaria's death in 1246 Fernando "era muy quexado et muy quebrantado del grant pesar que ouo; mas el fortelazamiento del su coraçon le fizo ende sofrir et encobrir su pesar": PCG, cap. 1073 (p. $748 \mathrm{a}_{29-32}$ ). Cf. JOINVILLE, loc. cit.; LE GoFF, p. 716.
} 
jouer?" ${ }^{36}$. Although we may prefer to characterize that chronicle as nanny's history rather than eirenic history, it would be wrong altogether to ignore contemporaneous historiographical developments in France, as they have have recently been identified, as a programmatic attempt, under royal auspices, and initiated around the year 1230, to reconcile the French nobility to the French monarchy after the defeat of the former at Bouvines in 1214, "offering a threatened elite a vehicle through which to recuperate a sense of social worth and political legitimacy"37.

There are differences between the two cases, of course, the most significant being that of language. Royally sponsored historiography in France was in the vernacular. Lucas of Tuy's chronicle was in Latin. This in turn raises the question of the audience which he and D. Rodrigo imagined they were addressing. In the case of D. Lucas and D. Rodrigo, however, the question of audience is probably yet another "question mal posée". Other considerations may have mattered more: institutional loyalty, for example. Also, sheer intellectual satisfaction. Students of medieval historiography, who assuredly do not study the subject for material profit, ought to be the first to appreciate the force of that. Then there is the issue of psychological motivation, a consideration of paramount importance in the case of a writer of the inventiveness of Pelayo of Oviedo in the eleventh century or Lucas of Tuy in the thirteenth: of that urge which, as has been suggested of an accomplished fraud of more recent times, "leads a man on, from mere disinterested craftsmanship, through a positive delight in his own virtuosity, to the exquisite private satisfaction of deceiving the elect" ${ }^{138}$. As to Lucas, in whom there seems to have been more than an element of intent to deceive the elect, all I would say is that if Queen Berengaria viewed either the Leonese or the Castilian aristocracy as "a threatened elite", and was counting on Lucas to provide "a vehicle through which [they might] recuperate a sense of social worth and political legitimacy", then she was likely to be disappointed. As Georges Martin has effectively demonstrated

\footnotetext{
${ }^{36}$ Thus E. BERgER, Histoire de Blanche de Castille, reine de France, Paris, 1895, p. 325.

${ }^{37}$ Gabrielle M. SPIEGEL, Romancing the Past. The rise of vernacular prose historiography in thirteenth-century France, Berkeley-Los Angeles-Oxford, 1993, p. 317, and chap. 6.

${ }^{38}$ H.R. TREVOR ROPER, Hermit of Peking. The hidden life of Sir Edmund Backhouse, Harmondsworth, 1978, p. 350. Cf. Umberto ECO, Tipologia della falsificazione, in Fälschungen im Mittelalter, I, "MGH" Schriften 33.i, Hanover, 1988, pp. 69-82; E.A.R. BROWN Falsitas pia sive reprehensibilis, Medieval forgers and their intentions, ibid., pp. 101-119.
} 
in his analysis of the case of the Judges of Castile, Lucas was not so much concerned to reconcile the territorial aristocracy as to pillory its members as subversives, disturbers by nature of the king's peace ${ }^{39}$. "Cauenda est etiam summopere discordia militaris" 40 .

Nor is that the only area in which Lucas's credentials as an angel of reconciliation must appear distinctly suspect. As Martin has argued, in his account of the confrontation between León and Castile in the decade after the death of Sancho III in 1158 Lucas is particularly partial ${ }^{41}$-though it has to be said that hard historiographical currency for the history of twelfth-century Spain is in such short supply that any argument of this sort is in danger of becoming circular ${ }^{42}$. It has also to be acknowledged that until we can refer to the forthcoming edition of Lucas by Dr Emma Falque we are all liable to be seriously misled.

In my own limited investigations of Lucas I have found that the text of Lucas published in 1608 and attributed to Mariana is regularly at variance with readings from the earliest surviving manuscripts of his work ${ }^{43}$. That said, my acquaintance with him amply confirms the impression of Georges Martin. As in his treatment of the themes of aristocracy-monarchy and León-Castile, so in his account of the ecclesiastical dimension of peninsular history Lucas is anything but an eirenic apostle of reconciliation. Quite the contrary. He is a sower of discord. To modify his own maxim: "Cauenda est etiam summopere discordia historiographica".

The perspective on the Spanish past from which Lucas of Tuy wrote was a Leonese perspective. "All history is contemporary history", said Croce. Menéndez Pidal knew and admired Croce. But in his work on the Alfonsine chronicles, that "excelente muchacho cuyo único defecto" (as it was reported of D. Ramón in 1894) "es la asiduidad con que se dedica a los

\footnotetext{
${ }^{39}$ MARTIN, Les Juges, pp. 212-229.

${ }^{40} \mathrm{Ibid}$., p. 235 n. 40 , citing $C M$, p. $39_{41-42}$.

${ }^{41}$ MARTIN, Les Juges, pp. 207-208.

${ }^{42}$ As Martin himself notes of Lucas's sources, p. 205, "la matière semble témoigner d'une enquête personelle à partir du règne d'Urraque de Castille" [1109].

${ }^{43}$ It may be noted in passing that the early MS. of the work (Lisbon, B.N. 353) listed by M.C. DíAZ Y DíAZ, Index scriptorum latinorum medii aevi hispanorum, Madrid, 1959, p. 1228 does not exist.
} 
cronicones de la Edad Media, creyendo, con la más absoluta candidez, que eso sirve para alguna cosa", made no allowance for Croce's dictum ${ }^{44}$.

Such was his concern with the text of the Alfonsine history that Menéndez Pidal failed to interrogate the sources of that history. He failed to allow for the possibility that the tributaries feeding that great Alfonsine river may have been contaminated. But in the study of historiographical processes contamination counts. Ask any glaciologist. Glaciologists have to put dyes into headwaters in order to discover the otherwise undiscoverable passage of underground streams. We are more fortunate. We already know how the streams run (or think we do). We may not know how they joined up, or through how many processes of refinement they passed before they entered and before they emerged from the taller alfonsi. We may not yet have identified the location and the contribution of the feeder streams. But we know, or we think we know, how the streams ran. And we know now that text alone is not all, we know that without context it is nothing, that, in the words of Leonardo Funes regarding the Alfonsine "textos-fuente": "Los textos no se interpretan sino que se usan, [...] no son sometidos a una desinteresada indagación de su exacto sentido, sino que se los utiliza, se les asigna funcionalidad orientada hacia el presente de la recepción" 45 .

And the same goes for the earlier stage in the process, for the elaboration of those very same "textos-fuente" and for the use and abuse of history which they exemplify. In this connexion the work of scholars such as Rico and, more recently, Martin and Fernández-Ordóñez must be regarded as fundamental, as also must that of Diego Catalán - though it is necessary to question Catalán's reiteration of the view that D. Rodrigo served as "fuente básica, de espinazo" of the Alfonsine Estoria. At the very least, the metaphor of Lucas of Túy as the ivy to D. Rodrigo's tree-trunk is unhelpful, if only to the extent that the ivy was flourishing well before the Rodrigan oak was planted ${ }^{46}$.

\footnotetext{
${ }^{44 "}$ "Lástima que inteligencias agudas y perspicaces como la suya se malgasten en tan ratoniles menesteres", F. NAVARRO LEDESMA (editor of Ganivet, not to say translator of Shakespeare's "Othello") continued: J. Pérez VIllanueva, Ramón Menéndez Pidal. Su vida y su tiempo, Madrid, 1991, p. 112.

${ }^{45}$ El modelo historiográfico alfonsi: una caracterización, "Papers of the Medieval Hispanic Research Seminar", London 1997, p. 17.

${ }^{46} \mathrm{D}$. CATALÁN, El taller historiográfico alfonsí. Métodos y problemas en el trabajo compilatorio, "Romania", 84 (1963) p. 359. Cf. IDEM, La Estoria de España de Alfonso X. Creación y evolución, Madrid, 1992, pp. 30, 33 (DRH as "fuente principal" and "el 'arbol' de
} 
As a Leonese historian, the sources Lucas used were principally Leonese sources. Where Lucas got much of his information from we do not know $^{47}$. Certain of his sources are identifiable. Others are not because Lucas invented them. In particular he invented sources for the history of seventh-century Spain, notably the Chronicle of S. Ildefonso to which I will come shortly. Lucas's seventh-century inventions were important (important to him) because on the face of it they made a contemporary point. (All history is contemporary history). Lucas's seventh-century sources, real and invented, all indicated that in the seventh century Seville had enjoyed ecclesiastical primacy over Toledo. The point of this in the 1230s was that Seville was about to be reconquered and that its reconquest would somehow reflect on Toledo. Here Lucas was concerned with the ecclesiastical dimension of Castilian-Leonese rivalry. The question of ecclesiastical primacy mattered in the thirteenth century for the same reasons as the hosting of the World Cup or the Olympic Games matters today: prestige and profit. By the 1230s other parts of the Western Church had passed this stage of development. The reason why Spain lagged behind was the existence of unreconquered areas of the Peninsula. Such contests may appear to us ridiculous. But it does not become an English medievalist to say so. It would not even become an English saint to say $\mathrm{so}^{48}$. After all, proprietory rights were involved, in this case those of the imposing Isidore of Seville, whose trustee Lucas was, and for centuries to come local communities would continue to enter into contracts of service with saints even more antique than Isidore ${ }^{49}$. Since 1085 Toledo had, by its own reckoning, been the capital of Castile, and, by the same token, the councils it had accommodated in the

la Estoria de España alfonsí al cual se vuelve una y otra vez para armar la historia"); p. 35 n. 96 ("Por lo general, Alfonso X, en caso de disentimiento entre don Rodrigo y don Lucas, da preferencia al testimonio del arzobispo, segun notó ya R. Menéndez Pidal...").

${ }^{47}$ For earlier speculation on the subject, see REILLY Sources, pp. 127-37; IDEM, Rodrigo Giménez de Rada's portrait of Alfonso VI of León-Castile in the "De Rebus Hispaniae": historical methodology in the thirteenth century, in "Estudios en homenaje a D. Claudio Sánchez Albornoz en sus 90 años", III, Buenos Aires, 1985, pp. 87-97.

${ }^{48} \mathrm{Cf}$. R.W. SOUTHERN's observation on St Anselm's defence of the interests of the church of Canterbury in the controversy concerning the English primacy c.1100: "With all his theological subtlety and insight into human behaviour he accepted the common views of the time in attributing to the saints in Heaven a concern for their worldly rights which, if they had not been part of an eternal order of the universe, would have disgraced a schoolboy": Saint Anselm. A portrait in a landscape, Cambridge, 1990, p. 346. 23-69.

${ }^{49}$ W.A. Christian, Jr., Local Religion in sixteenth-century Spain, Princeton, 1981, pp. 
seventh century entitled it to be regarded as the capital of Spain. Since 1230 Castile had acquired secular primacy over León. But in the seventh century Seville had accommodated councils too. Isidore had been bishop of Seville, not of Toledo. Also, there was much to be said against Toledo and its bishops. And Lucas said it. In addition to being a panegyric on León, Lucas's "Chronicle of the World" was a "Chronicle against Toledo".

As he wrote, Toledo and Castile enjoyed the enormous advantage of political supremacy. Lucas countered this by setting the historiographical agenda, in the manner of modern footballers by getting his retaliation in first. The particulars of how he did this I have attempted to describe elsewhere ${ }^{50}$. Here suffice it to say that under cover of the pious commission he had received Lucas was the thirteenth-century historiographical equivalent of the modern terrorist operating in occupied territory. His weapons were the land mine set on a main road and the booby-trap left in shop-doorways. Of the former a notable example was the chronicle he attributed to Ildefonso of Toledo $^{51}$. With the assistance of this, artfully ascribed to a Toledan authority, and of its fictitious villain Theodisclus, Isidore's apostate Greek successor at Seville, Lucas was able to explain how the primacy that Isidore of Seville had enjoyed passed to Toledo. Toledo owed its primacy to Teodisclus's apostasy, a poll of the episcopate, and the decision of King Wamba, incorporated into Lucas's text of that king's "hitación" whereby Toledo would continue to enjoy that distinction "for as long as it pleased this holy assembly" ("quandiu huic sancto coetui placuerit"), placing Toledo on probation until the successor in title of that royal holy assembly decided otherwise which with the restoration of the archbishopric of Seville imminent might not be long delayed ${ }^{52}$.

\footnotetext{
${ }^{50}$ LineHan, History, pp. $357 \mathrm{ff}$.

51 "que personne n'a pu identifier": MARTIN, Les Juges, p. 205. In fact it is spurious, as that acute scholar Juan Bautista Pérez spotted four hundred years ago: J. VILLANUEVA, Viage literario a las iglesias de España, III, Madrid, 1804, pp. 322-326. But the "Chronicle of Ildefonso" lived on. Not even Nicolas Antonio was aware of Pérez's demolition of it. It had taken early root. According to Alfonso X's famously critical contemporary, Juan Gil de Zamora, "Sanctus Illefonsus descripsit tempora Gothorum... usque ad octavum decimum [annum] Recensuyndi": JuAN GIL DE ZamORa, O.F.M., De preconiis Hispanie, ed. M. de CASTRO Y CASTRO, Madrid, 1955, p. 181. But nowhere did the Franciscan sage cite him.

${ }^{52}$ LINEHAN, History, pp. 376-9.
} 
D. Lucas was far from being the simpleton that he is generally taken for $^{53}$. Terrorists rarely are. Throughout his work there is ample evidence that the intelligence at work is both subtle and calculating, not that of a mitred cowherd. To serve his ideological purposes, he moves the establishment of the judges of Castile into the reign of Fruela II, rendering them rebels at a stroke ${ }^{54}$. More than that, by obliging D. Rodrigo to meet him on ground of his choosing, as well as wrong-footing the Castilian prelate who out-ranked him, he decisively influenced the scope and direction of large parts of the Alfonsine Estoria.

If it was Alfonso's imperial ambitions that provided the inspiration for his historiographical (as well as for his juridical) schemes, it was the strictly peninsular focus of his two main suppliers of information that determined the shape of his national history. If the Empire fuelled the engine, it was those suppliers' response to the course of the Reconquest that had laid the tracks.

I shall say rather less about Rodrigo as historian because he has received rather more attention than Lucas. He has also had a far better press. He has been generally regarded as trustworthy as a historian. On closer inspection this reputation may be found questionable ${ }^{55}$. D. Rodrigo wrote his history not at a queen's but at a king's behest, and of a king altogether more majestic and less plaster-saint-like than Lucas's imaginary monarch. Sapiencia and strenuitas come well before modestia in the job description the archbishop wrote for the prince he had in mind $^{56}$.

But if the agenda was the present then it was a present to be approached by way of the past, because that was the agenda which Lucas had set, and it was one which Rodrigo had no option but to follow.

\footnotetext{
${ }^{53}$ As by B. SÁNCHEZ AlONSO ("Otra acentuada faceta de su carácter es una credulidad que más parece de hombre del campo que de un cortesano letrado"): Historia de la historiografía española, I, Madrid, 1947, p. 126, and more recently by F.J. FERNÁNDEZ CONDE ("Accede a [sus] fuentes antiguas carente de todo sentido crítico" [emphasis Fernández Conde's]: El biógrafo contemporáneo de Santo Martino: Lucas de Túy: Isidoriana 1: "Ponencias del I Congreso Internacional sobre Santo Martino en el VIII centenario de su obra literaria (1185-1985)", León, 1987, p. 309.

${ }^{54}$ Martin, Les Juges, p. 219. "On ne peut qu'être fasciné par l'extrême finesse de l'écriture et du propos de Luc", Martin remarks, p. 233 n. 31. In the same sense, LinEHAN, History, pp. $369,371,384,405$.

${ }^{55} \mathrm{Ibid}$., pp. 350-84, and literature cited there.

${ }^{56}$ DRH (Prologus), p. 6 633.34; LINEHAN, History, pp. 298-299.
} 
In the words of Rodrigo's recent editor, "es la crónica del Obispo de Tuy la que a partir de este momento [the mid-eighth century] le va a servir de eje de la narración en el que se van ergarzando las demás". "El Tudense es el telón de fondo en el que se van enmarcando las demás crónicas"57. Dr Fernández Valverde attributes Rodrigo's attention to Lucas to the "estrecha amistad" which united them. "Quizás sea ésta la causa de que el Toledano enmascare en lo posible los pasajes que recoge de él", he suggests $^{58}$. I very much doubt it.

The fact was that in order to disarm Lucas Rodrigo had to be ready to deploy Lucas's own weaponry ${ }^{59}$. So in his preface he dutifully cites the phantom chronicle of San Ildefonso ${ }^{60}$. He even mentions Teodisclus (Isidore of Seville's insalubrious successor according to Lucas), though only in order to damage Seville of course. Perhaps he was as well aware as J. B. Pérez (not to mention Lucas) that no such person had ever existed ${ }^{61}$. Nevertheless, in the ex-Toledo manuscript of Lucas (now Madrid, Biblioteca Nacional, Ms. 10442), at this point the marginal signs appear thick and fast $^{62}$.

He omits awkward material. To avoid the difficulties created by Lucas's account of the "Hitación de Wamba" he ignores that capital event altogether, no matter that only recently it had been cited in court as evidence

${ }^{57} D R H$, pp. XXXI, XXXIII.

${ }^{58}$ Ibid., p. XXXIII.

${ }^{59}$ In a paper in press, L'escarboucle de Saint-Denis, le roi de France et l'empereur des Espagnes (for an advance copy of which I am extremely grateful to him), G. Martin analyses Rodrigo's treatment of Lucas's account of another event, the visit of Louis VII to Alfonso VII, and reaches conclusions similar to those presented here. See also LineHAN, History, pp. 276-277, 404

${ }^{60} \mathrm{DRH}$, prol., pp. $6_{65}-7_{72}$ : "Ea que ex libris beatorum Ysidori et Ildefonsi... compilaui". By "Ildefonso" J. GÓMEZ PÉREZ assumes Rodrigo to have meant Julián of Toledo (Manuscritos del Toledano, "Revista de Archivos, Bibliotecas y Museos", 60 [1954], p. 196). But in stating that Ildefonso had chronicled the period from the fifth year of Suinthila to the eighteenth of Reccesvinth (DRH, II.22: p. $73_{78}$ ), Rodrigo cannot have been referring either to any known work of Julián's or to Ildefonso's De uiris illustribus. It looks rather as if Rodrigo mentions Ildefonso as an insurance, because Lucas had done so.

${ }^{6} D R H$ II. 21 (p. $\left.71_{10-11}\right)$. Cf. VILLANUEVA, Viage literario, III. p. 325: "Nemo veterum talis historiae meminit...Tempore gotthorum nusquam nomen primatis nisi pro metropolitano, ut in concilio sub Gundemaro; neque de contentione primaciae usquam loquuntur auctores eius temporis".

${ }^{62}$ I discuss elsewhere the significance of the marginal marks in Ms. 10042. 
in the course of Toledo's litigation with Tarragona over the church of Valencia ${ }^{63}$.

Like Lucas, he changes dates to suit his own purposes. He moves the conciliar decree "Cum longe lateque", a key text in favour of Toledo's pretensions, from the year 681 to 675 , from the Twelfth Council to the Eleventh, thereby wrong-footing Lucas and decontaminating the stretch of history soiled by the latter's account of the "Hitación"64.

He misrepresents authentic authorities. In 672 Julian of Toledo had witnessed the anointing of King Wamba in the king's praetorian church at Toledo and had reported the fact in his Historia Wambae. Claiming Julian as his source, Rodrigo has the king anointed in the archbishop's cathedral ${ }^{65}$. Paraphrasing Clausewitz, we may say that for D. Rodrigo historiography was the continuation of litigation by other means.

In short, we are not so very far removed from the world of Santillana and Lafuente after all. "Tiene bastante honradez literaria para no desfigurar a sabiendas y por puro efectismo la verdad", A. Huici Miranda wrote of Rodrigo the historian ${ }^{66}$. But "a sabiendas" perhaps misses the essential point, which, whether in respect of Anselm of Canterbury in the eleventh century or of Rodrigo of Toledo in the thirteenth, was institutional loyalty. Wherever and whenever institutional loyalty was engaged, all writers of the age to which Anselm and Rodrigo belonged must be assumed guilty of what we moderns would regard as deception until proved innocent thereof.

Then there were other ideological programmes to be accommodated. Martin has already drawn attention to Rodrigo's reformulation of the legend of the Judges, inter alia in order to sustain an alternative view of society in which the right relationship of king and aristocracy is not hostility but coexistence ${ }^{67}$. In the same conciliatory spirit, on the ecclesiastical plane D. Rodrigo describes the baptismal scene of Spanish nationhood, the Third Council of Toledo in 589, which for Lucas had been a wholly royal affair

\footnotetext{
${ }^{63}$ LineHAN, History, pp. 341, 381; L. VÁzQUEZ DE PARGA, La División de Wamba, Madrid, 1943, p. 46.

${ }^{64}$ LineHAN, History, pp. 61, 366, 381-383.

${ }^{65}$ Ibid, pp. 387-388.

${ }^{66}$ Las grandes batallas de la Reconquista durante las invasiones africanas, Madrid, 1956, p. 303; and, in the same sense, GómEz PÉrEZ, Manuscritos del Toledano, p. 194.

${ }^{67}$ Les Juges, pp. 270-295.
} 
dominated by the "most religious" Reccared in all his glory, as a sort of cortes presided over by a constitutional monarch ${ }^{68}$.

Like Lucas, under cover of a commissioned royal history Rodrigo pursued an agenda of his own, which in his case was the prosperity and promotion of the church of Toledo. In the service of that cause he was at pains to diminish the significance of every other place which had harboured the Christian kings of Spain while Toledo had been under Islamic control. In the case of Oviedo, a note of scepticism is supplied by the insertion of the parenthetical "ut dicitur" into his borrowed narrative ${ }^{69}$. And the report from the ninth-century Crónica Albendense that Alfonso II had "recreated the glory of the Goths as it had been at Toledo" is undermined by the change of a single word, the effect of which is to make Toledo refulgent and cast Oviedo into the shade ${ }^{70}$.

As to León, the record is systematically purged. Lucas had stated that Ordoño II in 914 and Fernando I in 1038 had been anointed at León, Ordoño by twelve bishops and in the presence of all the magnates, prelates, counts and barons of Spain. Viewed from the thirteenth century, these were the two gala events of León's golden age. Rodrigo diminishes them both ${ }^{71}$. By removing all mention of anointing and describing both occasions simply as "coronations", he posthumously desacralises both monarchs, implying that it was to the acclamation of the aristocracy that Fernando owed his throne $^{72}$. Thus the historical record was established. For although in the

\footnotetext{
${ }^{68} \mathrm{DRH}$, II.15: "eidem concilio religiossisimus princeps deuotus aduenit gestaque concilii subscriptione firmauit abdicans, pontificibus et palacii primioribus, clero et milicia aprobantibus cum populo uniuerso, perfidiam..." (p. 62 $2_{14-15}$ ); P. LiNEHAN, Impacto del III Concilio de Toledo en las relaciones Iglesia-Estado durante el Medioevo, "Concilio III de Toledo. XIV Centenario. 589-1989", Toledo, 1991, p. 433. Cf. CM, p. 50 $0_{14-16}$ : "Cui concilio idem religiossisimus princeps interfuit, gestaque eius praesentia sua \& subscriptione firmauit, abdicans cum omnibus suis perfidiam..."

${ }^{69} \mathrm{DRH}$, IV.3, 8 (pp. $118_{4}, 125_{31},{ }_{33},{ }_{36}$; LINEHAN, History, p. 374.

${ }^{70} \mathrm{DRH}$, IV.8 (p. $125_{19-20}$ ): "Gothorum gloriam tam in ecclesiis quam in palaciis, ut olim Toleti fulserat, prout potuit, reparauit". Cf. Chron. Albendense, c.9: "omnemque Gotorum ordinem, sicuti Toleto fuerat, tam in eclesia quam palatio in Ouetao cuncta statuit" (ed. J. GIL Fernández, J.L. Moralejo, J.I. Ruiz de la PeÑa, Crónicas Asturianas, Oviedo, 1985, p. 174.99), whence $C M$, p. $74_{35}$ : "sicuti Toleto fuerat".

${ }^{71}$ Again, the marginalia to BN, Ms. 10042 are instructive.

${ }^{72} \mathrm{CM}$, p. $81_{10-13}$ : "Omnes siquidem Hispaniae magnates, Episcopi, Comites \& Barones facto conuentu solenniter generali, eum acclamando sibi Regem constituunt, impositoque illi diademate a duodecim pontificibus in solium regni Legione regia ciuitate perunctus est": cf. DRH, IV.22: "in eadem ecclesia comuni fauore principum et magnatum a XII pontificibus fuit diademate insignitus" (p. $146_{50-51}$ ). Likewise, $C M$, p. $92_{13}$ : Fernando I "consecratus...\& vnctus"
} 
Alfonsine History Fernando was to have his anointing restored to him, the other's inauguration would be recorded there as "alzamiento"73. And so Ordoño would be remembered down the centuries, as "rey alzado"74.

There are other examples in Rodrigo's History of the ceremonial downgrading of Lucas's civitas regia which might be noted, especially his account of the imperial coronation of Alfonso VII there in $1135^{75}$ - and very many others of what might be termed "strategic emendation" awaiting investigation. But the task will only be worth undertaking when we have access to the text of Lucas as Rodrigo would have had it. We cannot be sure that the ex-Toledo Cathedral copy (now BNM, Ms. 10442) was the only text of it he would have consulted (he was far too fly for that). And, as already said, the text of the 1608 "edition" is useless for our purposes now ${ }^{76}$.

For them then, however, for the Alfonsine compilers when they attempted to reconcile the two accounts, the problems must have been truly formidable. Having recently referred to their confusion between D. Lucas and D. Rodrigo in the case of the royal inauguration of Ordoño II, I will conclude with a further brief consideration of that issue.

"Es frecuente", Dr. Fernández-Ordóñez observes in her capital study of the "Versión crítica" of the Alfonsine Estoria,

que la opinión de Lucas de Tuy, cuando está relegada estructuralmente a segundo plano en la Estoria de España por ser divergente de la del arzobispo, se vea aún más degradada en la "Versión Crítica", al sustituir esa "versión" la fórmula que introduce respetuosamente la opinión del

by the bishop of León; cf. DRH, VI.9: "in regem ab omnibus est receptus et regali diademate... insignitus" (p. 186 9 9.11).

${ }^{73} P C G$, cap. 670, citing Lucas on the accession of Ordoño II at León: "et alli le alçaron rey; et fueron en ponerle la corona del regno XII obispos" (p. $383 \mathrm{~b}_{38-9}$ ). But this was not what Lucas had stated. In fact the compilers were following Rodrigo. Cf. the case of Fernando I's accession (PCG, cap. 802) where Lucas's version is preferred to Rodrigo's in terms which show that the compilers were perfectly capable of distinguishing coronation from anointing: "unciol estonces por rey...et pusol la corona del regno en la cabeça" (p. 483a $\mathrm{a}_{1-4}$ ).

${ }^{74}$ Thus Mariana, Historia, VII.20, records his coronation, while Modesto LafuenTE reports that he was elected by "los grandes de palacio" and the bishops "con arreglo á la antigua costumbre de los godos": Historia general de España, III, Madrid, 1850, p. 404

${ }^{75}$ LINEHAN, History, pp. 398-405; IDEM, León, ciudad regia, y sus obispos en los siglos $X-X I I I$, in El Reino de León en la Alta Edad Media, VI, León, 1994, pp. 411-57.

${ }^{70}$ See, for example, the variations in two of the earliest Lucas Mss. regarding Toledo and the "Hitación de Wamba", noted LineHan, History, pp. 379 n. 108. 
Tudense "pero dize aqui don Luchas de Tuy que" por la vaga expresión "algunos dizen que"77.

Now although, as I have indicated elsewhere, far from being "relegated" in the Estoria, Lucas's account of certain crucial incidents of the historical past actually prevails there ${ }^{78}$ it is undeniably significant that the account of Ordoño II's inauguration is eliminated altogether from the "Versión crítica"79. So too is the fact that it is Rodrigo's version of Alfonso VII's imperial coronation ("imposuit sibi imperii diadema"), rather than Lucas's ("fecit...imponere sibi coronam"), that is preferred ${ }^{80}$. The question is, why were these changes made, and how was it that the ideological inconsistency they represent was permitted? Cui bono?

We are at the end of the reign of Alfonso X - for yet another of Fernández-Ordóñez's achievements is her discovery that work was still in progress on the Estoria de España at that late date. The compiler responsible for extending the list of notorious usurpers in PCG cap. 559 (anno 711) to include the Infante Sancho must have been writing between 1282 and 221.

${ }^{77}$ I. FERNÁNDEZ-ORdóÑEZ, La Versión Crítica de la Estoria de España, Madrid, 1993, p.

${ }^{78}$ For example, though Lucas's lethal qualification, "quandiu huic sancto coetui placuerit metropolitanos", is absent from the Estoria's version of the "Hitación de Wamba", the Estoria nevertheless faithfully repeats Lucas's account of Seville's seventh-century primatial priority. "La siella arçobispal de Toledo tenga el primado entre todos los otros arçobispados de Espanna, e obedescan le estos obispados"; "All arçobispado de Seuilla, que fue la primera siella de las Espannas" (PCG, caps. 530, 531 [pp. 296b $\mathrm{b}_{13-15}, 297 \mathrm{a}_{15-16}$ ]; cf. $C M$, p. 57. : "Sedes subditas Hispalensi metropoli, quae hactenus prima fuit"). Moreover, in cap. 504, EE reproduces almost to the letter Lucas's (for Toledo) fateful description of the "translatio primaciae" by Chindasvinth: "Cindasvindo...enuio pedir all apostoligo un priuilegio tal, a plazer de los obispos de Espanna, que la dignidad del primado que fuesse en Toledo o en Seuilla, o el uiesse que era meior; et el papa otorgogelo...E por esta razon [Theodisto] torno el rey la dignidad del primado que auie la eglesia de Seuilla a la siella de Toledo, assi como la ouiera de antigo" (pp. $278 \mathrm{~b}_{5}-279 \mathrm{a}_{4}$. See LINEHAN, History, pp. 379-381, 384.

${ }^{79}$ Versión crítica, pp. 552-553. Cf. PCG, cap. 670; LineHAN, History, p. 471 n. 28.

${ }^{80}$ Information kindly provided by Mariano de la Campa, confirming FERNÁNDEZ-ORDÓÑEZ, Versión crítica, p. 227, to the effect that the text of the "Version crítica" is essentially identical to that of the so-called "Crónica de Veinte Reyes": "puso corona de enperador en su cabeça", according to Ms. J (ed. M. Alvar et al., Burgos, 1991, p. 263). Cf. LineHan, History, pp. 400-403, 463-466, 479-480; IDEM, From chronicle to history: concerning the Estoria de España and its principal sources, in A. DEYERMOND, ed., Historical Literature in Medieval Iberia, "Papers of the Medieval Hispanic Research Seminar" (Queen Mary and Westfield College London), London, 1996, pp. 20-23, 27-29. 
$1284^{81}$. However, this is not the only instance of 'actualización' to be found in the Alfonsine histories in these years. With the king's authority collapsing around him, the issue of the Castilian succession was of urgent interest to the compilers of the General Estoria too. As a rule, in common with Alfonso $\mathrm{X}$ 's translators from Arabic sources, these latter were much more faithful to the sources than their colleagues engaged on the national project ${ }^{82}$. Yet consider their paraphrase of 2 Samuel, 7:19: "E, Sennor, esta es la ley de Adan e du su linage que aya el padre cuydado de los fiios e que agradesca a Dios el bien e la merçed que le faze". The passage of scripture they were paraphrasing contains no mention of either lineage or sons ${ }^{83}$. Discipline was cracking.

It is not altogether difficult to understand why. In their steady progress through biblical history they had reached the rebellion of Adonijah, the son of David, the king of Israel whose history presented certain uncanny resemblances with that of their master, the king of Castile. David was thirty when he began to rule over Israel, "and in Jerusalem he reigned thirty and three years over all Israel and Judah" 84 . Alfonso had also been thirty when he succeeded as king of Castile and León, and the thirty-third year of his reign commenced at the end of May $1283^{85}$.

And by the end of May 1283 he was more or less at the mercy of his rebel sons, led by the Infante Sancho. It is to that extent instructive to find the compilers of the General Estoria presenting the rebellion of Adonijah as a conspiracy of all David's sons and as an example of how the ambitious sons of kings always behaved. "Et los fijos de los reyes que querian regnar metien se antes a fazer algunas cosas de aquellas que

\footnotetext{
${ }^{81}$ FERNÁNDEZ-ORdóÑEZ, Versión crítica, pp. 54-55: "Alçararonse con don Sancho todos los del rregno e ajuramentaronse contra el rrey para prenderle e echarle de la tierra"; pp. 222-224. (What immediately follows - "mas ayudole Dios e los de Seuilla e el rrey Abenenjufal de los abonmarines a ese rrey don Alfonso, asy commo adelante lo diremos en su lugar" - implies high confidence on the part of the compilers regarding the time left to them to revise the next 570 years of history).

${ }^{82}$ I. FERNÁNDEZ-ORdóñEZ, Las "Estorias" de Alfonso el Sabio, Madrid, 1992, pp. 100, 103; J.M. Millás VAlliCrosa, El literalismo de los traductores de la corte de Alfonso X el Sabio, "al-Andalus", I (1933), p. 155.

${ }^{83}$ General estoria [hereinafter GE], II, ed. L.A. KASTEN and V.R.B. OELSCHLÄGER, pt II, Madrid, 1961 , p. $361 b_{40-43}$.

${ }^{84} G E$, p. $358 b_{26-28} ;$ II Sam. 5:5.

${ }^{85}$ Cf. LineHAN, History, pp. 485-486.
} 
conuienen a fazer a los reyes", they noted ${ }^{86}$. They noted the fact that Adonijah and Absalom were brothers, referred to Absalom's earlier insurgency, and commented that in parading around the country in royal fashion Adonijah had been behaving "como fijo de rey que ouiesse a regnar" 87 . Here they were on familiar territory, and their message was only lightly coded. By openly challenging their father's authority, Adonijah and his brothers had provided rôle-models for the Infante Sancho and his, for the other infantes whom Sancho had suborned, as their disenchanted father was firmly convinced, in the weeks before the final rupture of April $1282^{88}$.

It would probably be wrong to reduce the study of Alfonsine historiography altogether to the level of the psychiatrist's couch. Even so, it is permissible to ask how much more dispassionate the compilers of the Alfonsine History really were, at least at this late stage of the operation, than their principal purveyors of information had been almost half a century before. We may also wonder, for example, why it was that Alfonso X's research department, which famously searched far and wide for ancient materials, failed to make use of (I do not say failed to find) such recent works as the "Crónica latina de los reyes de Castilla"89, or D. Rodrigo's Breviarium Historie Catholice - that exhaustive survey of biblical history closely modelled on Petrus Comestor's Historia scholastica which on the

\footnotetext{
${ }^{86} G E$, p. $393 \mathrm{~b}_{10-13}$.

${ }^{87}$ Ibid., p. 393b ${ }_{25.6}$; LINEHAN. History, pp. 492-494. The argument presented there against deriving a terminus ante quem for Part II of $G E$ from the date 1280 attached to the Vatican manuscript of its Part IV has since been corroborated by Fernández-Ordóñez's evidence as to the "actualización" of the text of $E E$ in 1282-1284 -though, admittedly, the allusion to rebel sons would have had equal resonance at any time over the previous decade. Cf. F. RICO, Alfonso el Sabio y la "General estoria", 2nd edn, Barcelona, 1984, pp. 108-120.

${ }^{88} \mathrm{Cf}$. Alfonso X's charge against the Infante Sancho in November 1283: "Predicta autem omnia non solum per se fecit dictus Sanctius, sed etiam per fratres suos"; "Et porque a los otros nuestros fijos metió [Sancho] en estos fechos faciéndoles entender falsedades et enemigas, porque se hobieron a mover contra nos muy cruelmente...": J. de ZURITA, Indices rervm ab Aragoniae regibvs gestarv'm ab initiis Regni ad ann'm MCDX..., Zaragoza, 1578, p. 172; A.G. Solalinde, Antología de Alfonso X el Sabio, 6th edn, Madrid, 1977, pp. 227-228. Cf. LINEHAN, History, pp. 493-7; I. FERNÁNDEZ-ORDÓÑEZ, La historiografía alfonsi y post-alfonsi en sus textos: nuevo panorama, "Cahiers de lingüistique hispanique médiévale", XVIII-XIX (1993-4), p. 124.

${ }^{89}$ REILLY, Sources, p. 131, suggests that Lucas "may possibly have been able to draw" upon this source. It is difficult to see how.
} 
face of it must surely have had some useful purpose to serve somewhere within the Alfonsine workshop ${ }^{90}$.

And, in the same spirit, might it not also be asked whether the Seville-Toledo contest of the seventh century, which mattered so much to their respective champions in the thirteenth, may not have mattered to Alfonso $\mathrm{X}$ too in the last sad months of his life -indeed whether corporate loyalties to one place or the other amongst the Alfonsine compilers may not even have been influential within the taller alfonsí itself over the previous decade or more. After all, not only did the different teams of compilers enjoy a considerable degree of independence in their labours ${ }^{91}$. Since Seville and Toledo were their principal centres of activity, it may reasonably be conjectured that individuals within them were to some degree associated with either one place or the other, at least by adoption, and harboured some sense of corporate loyalty. It may even be that the loyalty to Alfonso X which Seville maintained to the very end, by contrast with Toledo's adherence to the Infante Sancho after 1282 and the equivocation of its archbishop ${ }^{92}$, came eventually to influence the king's own fractured judgement regarding the respective merits of those two places. But admittedly, this $i$ conjecture. There can be no saying for sure. For, as the conflicting accounts of the seventh-century controversy prompted the king's compilers ruefully to reflect, "la uerdad de la historia a las vezes es dubdosa"93.

${ }^{90}$ Ed. J. Fernández VAlverde, CCCM 72A-B, Turnout, 1992, 2 vols. Cf. my review, "Journal of Ecclesiastical History", 46 (1995), pp. 143-146, and the conviction of J. GÓMEZ PÉREZ that methodologically the General Estoria"indudablemente se inspiró en la obra del arzobispo Toledano": El historiador Jiménez de Rada y las tierras de Soria, "Celtiberia", 6 (1955), p. 167.

${ }^{91}$ FernándeZ-Ordóñez, Las "Estorias" de Alfonso el Sabio, pp. 53-67; FunEs, El modelo historiográfico, p. 19: "Lo que puede identificarse como el modelo alfonsí fue fruto de una tarea colectiva $y$, aunque tenia una indudable unidad ideológica, la diversidad de técnicas y procedimientos para afrontar los mismos problemas de representación histórica nos lleva a visualizarlo como una ancha avenida en la que cada equipo realizó su trabajo de escritura por un carril propio".

${ }^{92}$ Although not until December 1283 was the archbishop of Toledo, Gonzalo Pérez, compelled to declare himself (Toledo, Archivo de la Catedral, E.7.C.1.7), his position had been in doubt since April 1282. On this, and the case for regarding him as responsible for the "Toledanization" of the Alfonsine Estoria after 1284, see LinEHAN, History, 448-449, 463-480; LINEHAN and F.J. HERNÁNDEZ (forthcoming).

${ }^{93} P C G$, cap. 571: "Mas los escriptos son muchos et cuentanlo de muchas guisas, por que la uerdad de la estoria a las vezes es dubdosa, e por ende el que lee meta mientes como de las meiores escripturas tome lo que deue prouar et leer" (p. 326 $\mathrm{b}_{31-36}$ ). (Thus FERNÁNDEZ-ORDÓÑEZ, 


\section{RÉSUMÉ}

La renaissance de l'historiographie dans la Castille à la quatrième décade du XIII siècle ne va pas de soi et mérite donc une explanation. Nous suggérons ici quelques pistes possibles et analysons la relation entre les principaux acteurs de ce phénomème, Lucas de Tuy et Rodrigue de Tolède, ainsi que leurs contributions respectives au développement de l'histoire Alphonsine. Nous nous intéressons aussi à l'influence des évolutions contemporaines sur les choix personnels de loyauté des compilateurs de cette histoire.

\section{SUMMARY}

The revival of historiographical activity in early thirtheenth-century Castile requires explanation. It is not self-evident. Some possible reasons are suggested here, and the interplay between the principal actors in the process, Lucas of Tuy and Rodrigo of Toledo, is further investigated, as are their respective contributions to the development of the Alfonsine history and the sensitivity of its compilers both to contemporary developments and to their own private loyalties.

La Versión Crítica, p. 372). 